\title{
On the Relationship between Iranian EFL Learner's Musical and Visual Intelligences and their Use of Speaking Strategies in Communication
}

\author{
Elham Sadripour (Corresponding author) \\ English Department, Islamic Azad University, Torbat-e-Heidarieh Branch, Iran \\ E-mail: elhamsadripoor@gmail.com \\ Khalil Motallebzadeh \\ English Department, Islamic Azad University, Torbat-e-Heidarieh Branch, Iran \\ E-mail: k.motalleb@iautorbat.ac.ir
}

Received: 07-06-2015

Published: 01-01-2016
Accepted: 25-09-2015

doi:10.7575/aiac.ijalel.v.5n.1p.162
Advance Access Published: October 2015

URL: http://dx.doi.org/10.7575/aiac.ijalel.v.5n.1p.162

\begin{abstract}
Review of the past literature on the characteristics of successful language learners indicates that more successful learners are those who apply more strategies. Although a sizeable number of studies were conducted on language learning strategies, there is a limited amount of research with focus on speaking strategies. This study aimed to investigate the relationship between Iranian EFL learners' musical and visual intelligences and their use of speaking strategies in communication. Gender differences regarding the use of speaking strategies were also examined in this research. Participants in this study were three hundred and sixty undergraduate EFL learners from several universities in Iran who were presented with a questionnaire including McKenzie's Multiple Intelligences Inventory and Oral Communication Strategy Inventory (OCSI). Results of data analysis revealed that there is a significant relationship between EFL learners' musical and visual intelligences and their use of speaking strategies. Results of more analysis indicated significant relationship between musical intelligence and accuracy-oriented and fluency-oriented strategies, and visual intelligence and social affective and negotiation for meaning strategies. Findings also revealed that females were superior in using some strategy types including message reduction and nonverbal strategies.
\end{abstract}

Keywords: Speaking Strategies, Musical Intelligence, Visual Intelligence, Gender

\section{Introduction}

Haward Gardner introduced theory of multiple intelligences in 1983. Gardner (1983) defined intelligence as "the ability to solve problems or to create products that are valued within one or more cultural settings" (p. 10). According to Gardner's multiple intelligences theory all human beings posses at least nine types of intelligences (i.e. linguistic, logical-mathematical, interpersonal, bodily-kinesthetic, intrapersonal, musical, naturalist, spatial and existential intelligences) while they are different in combination and strength. Gardner believed that genetics and environment are two factors which determine the profile of intelligence. Individuals are different psychologically because their experiences are different. Later, the application of MI theory in educational context specifically in EFL context attracted the attention of many researchers.

Heidari and Khorasaniha (2013), in their study, examined the relationship between Locus of control (LOC), Multiple Intelligences (MI), and reading proficiency of EFL learners. Results showed no significant relationship between LOC and MI but a significant relationship was found between MI and reading proficiency. Also a significant relationship between LOC and reading proficiency was found.

Another study was conducted by Motallebzadeh (2009) in order to investigate the relationship between Emotional Intelligence and EFL learners' reading comprehension and structural ability. Findings of this study indicated a strong relationship between Emotional Intelligence and EFL learners' reading comprehension and structural ability.

Mohammadzadeh and Jafarigohar (2012) in their study examined the relationship between willingness to communicate (WTC) and multiple intelligences (MI). Also the effect of gender on the relationship between these two constructs was explored. In this research 500 EFL learners were asked to fill out WTC and MI questionnaires. Findings showed that there was a significant correlation between learners' MI profile and their willingness to communicate. Besides, results indicated that gender affected the relationship between willingness to communicate (WTC) and multiple intelligences (MI).

In a similar line of inquiry, Khosravi and Saidi (2014) examined the relationship between Iranian English for academic purposes (EAP) instructors' interpersonal and intrapersonal intelligences and their self-efficacy beliefs. Participants in this study were 120 language and content English for academic purposes instructors who were presented by two 
questionnaires, McKenzie's (1990) Multiple Intelligences Questionnaire and Tschannen-Moran and Woolfolk Hoy's (2001) Teachers' Sense of Efficacy Scale. Results indicated a positive significant correlation between personal intelligences and self-efficacy.

Hajhashemi, Akef and Anderson (2012) conducted a study to investigate the possible relationship between Multiple Intelligences and Reading Proficiency of Iranian EFL Students. The role of gender was also examined in this study. To this end, 128 students were asked to complete demographic questionnaire, MI questionnaire and a reading comprehension test. Results of this study indicated that low achievers in reading proficiency had a higher musicalrhythmic intelligence while high achievers were less intelligent musically. Also it was found that females obtain higher bodily-kinesthetic intelligence scores in comparison with males. There was not a significant difference in reading scores of male and female students.

Brown (2007, p. 132) mentioned that "strategies are those specific "attacks" that we make on a given problem, and that vary considerably within each individual". According to O'Malley and Chamot (1990), learning strategies are "complex procedures that individuals apply to tasks; consequently, they may be represented as procedural knowledge which may be acquired" (p. 52). Mitits and Sarafianou (2012) in their study referred to recent research (i.e., Cohen, 2005, Griffiths 2008, Oxford 1990, 2011) which explained the main characteristics of Language Learning Strategies (LLS). They referred to LLS as mental activities which adjust learning and form strategy clusters. Learners choose them to promote successful learning. They are teachable and can be helpful for the teachers in order to increase their role in class. There are different classifications of language learning strategies in the field of second language acquisition.

Today improving communicative competence of EFL learners is a concern of many English teachers. Hedge (2000) believes that a competent speaker should know how to use speaking strategies. Hedge (ibid.) explains that: "These strategies come into play when learners are unable to express what they want to say because they lack the resources to do so successfully" (as cited from López, 2011). According to Selinker (1972), only few language learners achieve native like language proficiency and the result of learners' attempt to communicate in meaningful situations is an imperfect language which has the characteristics of both their native and target language which Selinker termed interlanguage. Selinker (1972) included use of strategies for second language communication as one of the five central processes of interlanguage occurring when learner without necessary linguistic skill tries to communicate something in target language (cited from Metcalfe and Noom-Ura, n.d).

During past decades many studies were conducted in order to investigate use of language learning strategies among EFL learners. Tam (2013) conducted a study to investigate the relationship between second language proficiency, socioeconomic status, gender and language learning strategies (LLSs). To this end 50 first year university students were presented by SILL questionnaire as an instrument. Findings revealed that these factors would affect the user's use of LLSs. Results also indicated that there were significant differences between males and females in using Memory, Cognitive, Compensation, Social, and Metacognitive Strategies to learn English. Females use all of these strategies more than males. In addition, a positive correlation between users' second language proficiency and Compensation, Cognitive, and Social Strategies was found. Results also indicated that socioeconomic status would significantly affect local university students' use of Social Strategies.

Grainger (2012) in a study about the impact of cultural background on the choice of language learning strategies in the JFL context concluded that the choice of strategies by learners of Japanese in Australia was significantly affected by cultural background. Grainger (2012) mentioned that these differences were at the item level, not the category level, so researchers should consider the micro level analyses as well as the category analyses. It was found that Asian students not only use more strategies but also use them in different ways. Granger concluded that language learning environment is an important factor in the choice of strategies (Grainger, 2012).

Davar Asl Bandarabbasi and Karbalaei (2013) in their study investigated the Relationship between Multiple Intelligences and Learning Strategies among 70 homogenous Iranian EFL learners, who were presented by two tests, MI inventory, prepared by Armstrong (1994) and learning strategy questionnaire developed by Oxford (1990). Findings revealed significant relationships between bodily-kinesthetic intelligence and meta-cognitive strategies, musical intelligence and meta-cognitive strategies and linguistic intelligence and social strategies.

It seems that there are not enough studies to examine speaking strategies in EFL context and also according to Mistar and Umamah (2014), the findings of studies which they reviewed revealed that the effect of gender on the choice of speaking strategies is not yet conclusive, so the current study aims to investigate the relationship between Iranian intermediate EFL learners' visual and musical intelligences and their use of speaking strategies in communication and also any significant differences between Iranian male and female EFL learners regarding their use of speaking strategies. To address the objectives of the study, the researcher posed the following research questions:

Q1. Is there any significant relationship between Iranian intermediate EFL learners' visual intelligence and their use of different speaking strategies?

Q2. Is there any significant relationship between Iranian intermediate EFL learners' musical intelligence and their use of different speaking strategies?

Q3. Are there any significant differences between Iranian male and female EFL learners regarding their use of speaking strategies?

In order to answer research questions, the following null hypotheses were formulated: 
H01. There is no significant relationship between Iranian intermediate EFL learners' visual intelligence and their use of different speaking strategies.

H02. There is no significant relationship between Iranian intermediate EFL learners' musical intelligence and their use of different speaking strategies.

H03. There are not any differences between males and females regarding the use of speaking strategies.

\section{Method}

\subsection{Participants and Setting}

Three hundred and sixty intermediate undergraduate EFL learners (188 females and 172 males) from several universities in Iran (Tehran, Mashhad, Esfahan, Birjand, and Gorgan) participated in this study. Sample size was determined According to Morgan's table, (Morgan, 1970 "Determining Sample Size for Research Activities", Educational and Psychological Measurement) (Considering the 95\% of the level of confidence and 0.05 degree of accuracy). Participants were native speakers of Farsi and their age ranged between 18 and 25. These students were majoring in Teaching English as a Foreign Language (TEFL), English Translation, and English Language Literature in public universities. Table 1 shows participants' demographic information including their number and gender.

Table 1. Participants' Demographic Information

\begin{tabular}{clcccc}
\hline \multirow{3}{*}{ Gender } & Frequency & Percent & $\begin{array}{c}\text { Valid } \\
\text { Percent }\end{array}$ & $\begin{array}{c}\text { Cumulative } \\
\text { Percent }\end{array}$ \\
\cline { 2 - 6 } & Female & 188 & 52.2 & 52.2 & 52.2 \\
& Male & 172 & 47.8 & 47.8 & 100.0 \\
& Total & 360 & 100.0 & 100.0 & \\
\hline
\end{tabular}

According to Table 1, total number of participants was 360 EFL learners including 188 females and 172 males.

\subsection{Instrumentation}

\subsubsection{McKenzie's Multiple Intelligences Inventory}

Persian version of McKenzie's Multiple Intelligences (MI) Inventory (1999) which includes nine sections measuring nine types of intelligences (natural, musical, logical/mathematical, intrapersonal, interpersonal, bodily/kinesthetic, linguistic, existential, and spatial/visual intelligences) was administered. Each section consists of 10 items which were five-point Likert scale ranging from 1(completely disagreed) to 5 (completely agreed). Hajhashemi and Bee Eng (2010) checked the validity of the Persian version of this questionnaire, also they reported a high reliability for the Persian version of this questionnaire (Hajhashemi \& Bee Eng, 2010). In this study the researcher had a special focus on musical and visual intelligences so the number of questions in this study decreased to 20 questions (musical 10 items and visual 20 items).

\subsubsection{Speaking Strategy Questionnaire}

Oral Communication Strategy Inventory (OCSI) developed by Nakatani (2006) was another instrument in this study. This is a 58-item likert scale questionnaire which includes 32 strategies for coping with speaking problems and 26 strategies for coping with listening problems. The reliability index of 0.96 was reported for this questionnaire in the study of Shangarffam and Zand (2012). In the current study speaking strategy section of OCSI was used. The reliability of speaking section of this questionnaire was found to be 0.83 . Speaking strategy section includes eight categories which were: accuracy-oriented strategies, social affective strategies, negotiation for meaning while speaking, fluencyoriented strategies, message abandonment strategies, nonverbal strategies while speaking, attempt to think in English strategies, and message reduction and alteration strategies. Students should answer to this questionnaire by choosing from five Likert scales ranging from "never" to "always". To check the reliability Index of the Instruments, Cronbach's Alpha was calculated for both of the questionnaires. Table 2 shows the results.

Table 2. Results of Reliability

\begin{tabular}{ccc}
\hline Questionnaire & N of items & Cronbach's Alpha \\
\hline Speaking Strategies & 32 & .83 \\
\hline Musical \& visual intelligences & 20 & .70 \\
\hline
\end{tabular}

As Table 2 indicates, Speaking Strategies $(\alpha=.83)$ and musical and visual Intelligences $(\alpha=.70)$ enjoyed relatively high reliability indexes.

Participants were required to provide some demographic information such as gender, level of language proficiency, and age. 


\subsection{Procedure}

Three hundred and sixty EFL learners (188 females and 172 males) were participants of this study. They were intermediate undergraduate students whose age ranged between 18 and 25. As instruments McKenzie's Multiple Intelligences (MI) Inventory (1999) and Oral Communication Strategy Inventory (OCSI) were used in this study and Participants were presented by a test including these two questionnaires. The reliability coefficients of both questionnaires were calculated via Cronbach's alpha, which were 0.70 and 0.83 respectively. Some participants received the test in form of paper and the others received it via internet. The purpose of study was explained for the participants at the beginning of the questionnaire and they were asked to answer the questions in 50 minutes. The test was administered among more than 1000 EFL learners during the academic year of 2014-2015, but only three hundred and sixty intermediate EFL learners answered the test completely. Researcher excluded questionnaires which were incomplete or their participants' level of language proficiency were not intermediate. Data analysis was done using SPSS software 20.0.

\subsection{Study Design}

This study aimed to investigate the possible relationship between Iranian intermediate EFL learners' visual and musical intelligences and their use of speaking strategies in communication. For this reason correlational/ex post facto design was used.

\section{Results}

\subsection{Musical and visual Intelligences}

In order to investigate participants' musical and visual intelligences, descriptive statistics including mean, minimum, maximum and standard deviation were calculated. The results are shown in Table 3.

Table 3. Descriptive Statistics for musical and visual Intelligences

\begin{tabular}{lccccc}
\hline & $\mathrm{N}$ & Minimum & Maximum & Mean & Std. Deviation \\
\hline Visual & 360 & 19.00 & 44.00 & 35.96 & 4.08822 \\
\hline Musical & 360 & 24.00 & 47.00 & 35.76 & 4.55026 \\
\hline Valid N (listwise) & 360 & & & & \\
\hline
\end{tabular}

As Table 3 shows, mean of visual intelligence and musical intelligence are $M=35.96$, and $M=35.76$ respectively.

\subsection{Speaking Strategies}

Table 4 shows the results of descriptive statistics related to speaking strategies (i.e. social affective, fluency-oriented, negotiating for meaning, accuracy-oriented, message reduction, nonverbal strategy, message abandonment, and attempt to think in English).

Table 4. Descriptive Statistics for Speaking Strategies

\begin{tabular}{cccccc}
\hline Descriptive Statistics & & & & & \\
& $\mathrm{N}$ & Minimum & Maximum & Mean & Std. Deviation \\
\hline SA & 360 & 2.17 & 4.83 & 3.6542 & .49047 \\
\hline FL & 360 & 2.33 & 5.00 & 3.8657 & .61237 \\
\hline NFM & 360 & 2.25 & 5.00 & 3.9368 & .69318 \\
\hline AC & 360 & 2.00 & 5.00 & 3.8467 & .60879 \\
\hline MES & 360 & 3.00 & 5.00 & 3.8646 & .53301 \\
\hline NVS & 360 & 1.00 & 5.00 & 3.9861 & .84845 \\
\hline MA & 360 & 1.25 & 4.25 & 2.5243 & .71562 \\
\hline ATE & 360 & 1.00 & 5.00 & 3.2500 & .93000 \\
\hline Valid N (listwise) & 360 & & & & \\
\hline
\end{tabular}

According to Table 4, nonverbal strategy (NVS) has the highest mean $(\mathrm{M}=3.98)$ and message abandonment gained the lowest mean (MA, M=2.52). Negotiation for meaning (NFM, M=3.93). Fluency-oriented (FL, M=3.8657), Message reduction ( $\mathrm{MES}, \mathrm{M}=3.8646$ ), Accuracy-oriented ( $\mathrm{AC}, \mathrm{M}=3.84$ ), Social affective ( $\mathrm{SA}, \mathrm{M}=3.65)$, Attempt to think in English (ATE, M=3.25) are in second to seventh places respectively.

\subsection{Relationship between musical and visual Intelligences and Use of Speaking Strategies}

In order to see whether there is a statistically significant correlation between the participants' musical and visual intelligences and their use of speaking strategies, Pearson product Moment Correlation Coefficient was calculated (Table 5). 
Table 5. Results of Relationship between Musical\& visual Intelligences and Use of Speaking Strategies

\begin{tabular}{|c|c|c|c|}
\hline \multicolumn{4}{|l|}{ Correlations } \\
\hline \multirow[b]{2}{*}{$\begin{array}{l}\text { Musical\& visual } \\
\text { intelligences }\end{array}$} & & $\begin{array}{c}\text { Musical\& visual } \\
\text { intelligences }\end{array}$ & Strategies \\
\hline & $\begin{array}{l}\text { Pearson } \\
\text { Correlation }\end{array}$ & 1 & $.121 *$ \\
\hline \multirow{5}{*}{ Strategies } & Sig. (2-tailed) & & .022 \\
\hline & $\mathrm{N}$ & 360 & 360 \\
\hline & $\begin{array}{l}\text { Pearson } \\
\text { Correlation }\end{array}$ & $.121 *$ & 1 \\
\hline & Sig. (2-tailed) & .022 & \\
\hline & $\mathrm{N}$ & 360 & 360 \\
\hline
\end{tabular}

Table 5 confirms that EFL students' Musical\& visual intelligences is significantly [ $\mathrm{r}=.121$, sig (two-tailed) $=.022<.05]$ correlated with their use of speaking strategies.

In order to see which speaking strategies are preferred by different types of intelligence, Pearson Product Moment Correlation Coefficient test was conducted.

\subsection{Relationship between Visual Intelligence and Speaking Strategies}

In the next phase, correlation between visual intelligence and each component of speaking strategies was investigated (Table 6).

Table 6. Results of Correlation between Visual Intelligence and Speaking Strategies

\begin{tabular}{|c|c|c|c|c|c|c|c|c|c|c|}
\hline \multicolumn{11}{|c|}{ Correlations } \\
\hline & & visual & SA & $\mathrm{FL}$ & NFM & $\mathrm{AC}$ & MES & NVS & MA & ATE \\
\hline \multirow[t]{3}{*}{ visual } & $\begin{array}{l}\text { Pearson } \\
\text { Correlation }\end{array}$ & 1 & $.189^{* *}$ & -.090 & $.139^{*}$ & .071 & .081 & .065 & -.020 & .029 \\
\hline & Sig.(2-tailed) & & .000 & .090 & .008 & .181 & .123 & .216 & .709 & .584 \\
\hline & $\mathrm{N}$ & 360 & 360 & 360 & 360 & 360 & 360 & 360 & 360 & 360 \\
\hline
\end{tabular}

As table 6 displays, there is a statistically significant correlation between visual intelligence and social affective strategies $[\mathrm{r}=.189$, sig (two-tailed) $=.000<.05]$ and negotiation for meaning strategies [r=.139, sig (two-tailed) $=.008<.05]$. Other speaking strategies are not significantly correlated with logical intelligence $(\mathrm{sig}>.05)$. It can be concluded that participants who are more visually intelligent employ strategies from the social affective and negotiation for meaning categories.

3.5 Relationship between Musical Intelligence and Speaking Strategies

Then, the correlation between musical intelligence and each component of speaking strategies was explored (Table 7).

Table 7. Results of Correlation between Musical Intelligence and Speaking Strategies

\begin{tabular}{|c|c|c|c|c|c|c|c|c|c|c|}
\hline \multicolumn{11}{|c|}{ Correlations } \\
\hline & & Musical & SA & FL & NFM & $\mathrm{AC}$ & MES & NVS & MA & ATE \\
\hline \multirow[t]{3}{*}{$\begin{array}{l}\text { Musi } \\
\text { cal }\end{array}$} & $\begin{array}{l}\text { Pearson } \\
\text { Correlation }\end{array}$ & 1 & .013 & $.143^{* *}$ & .018 & $.166^{* *}$ & .013 & .08 & -.007 & -.004 \\
\hline & $\begin{array}{l}\text { Sig. } \\
\text { (2-tailed) }\end{array}$ & & .805 & .007 & .731 & .002 & .813 & .12 & .889 & .941 \\
\hline & $\mathrm{N}$ & 360 & 360 & 360 & 360 & 360 & 360 & 360 & 360 & 360 \\
\hline \multicolumn{11}{|c|}{ **. Correlation is significant at the 0.01 level (2-tailed). } \\
\hline
\end{tabular}


According to Table 7, musical intelligence is significantly correlated with fluency-oriented strategies [ $\mathrm{r}=.143$, sig (twotailed) $=.007]$ and accuracy-oriented strategies $[\mathrm{r}=.166$, sig (two-tailed) $=.002<.05$ ) $]$. As a result, it can be concluded that EFL students who are more musically intelligent employ strategies like fluency-oriented and accuracy-oriented more frequently.

\subsection{Difference between Male and Female Learners Regarding Their Use of Speaking Strategies}

In order to see whether there is any statistically significant difference between means obtained by males and females in different categories of speaking strategies, independent samples t-test was conducted. Table 8 shows the relevant data.

Table 8. Results of Independent Samples T-test for Difference between Males and Females Regarding Use of Speaking Strategies

\begin{tabular}{|c|c|c|c|c|c|c|c|}
\hline & Gender & $\mathrm{N}$ & Mean & Std. Deviation & $\mathrm{df}$ & $\mathrm{t}$ & Sig(two tailed) \\
\hline \multirow[t]{2}{*}{ SA } & female & 188 & 3.6871 & .47582 & 358 & 1.33 & .18 \\
\hline & male & 172 & 3.6182 & .50492 & & & \\
\hline \multirow[t]{2}{*}{ FL } & female & 188 & 3.8528 & .63791 & 358 & .418 & .67 \\
\hline & male & 172 & 3.8798 & .58470 & & & \\
\hline \multirow[t]{2}{*}{ NFM } & female & 188 & 3.9122 & .76365 & 358 & .70 & .48 \\
\hline & male & 172 & 3.9637 & 60799 & & & \\
\hline \multirow[t]{2}{*}{$\mathrm{AC}$} & female & 188 & 3.8862 & .66092 & 358 & 1.28 & .19 \\
\hline & male & 172 & 3.8035 & .54482 & & & \\
\hline \multirow[t]{2}{*}{ MES } & female & 188 & 3.9408 & .52622 & 358 & 2.71 & .007 \\
\hline & male & 172 & 3.7890 & .53259 & & & \\
\hline \multirow[t]{2}{*}{ NVS } & female & 188 & 4.1090 & .79104 & 358 & 2.90 & .004 \\
\hline & male & 172 & 3.8517 & .89007 & & & \\
\hline \multirow[t]{2}{*}{ MA } & female & 188 & 2.5465 & .75211 & 358 & .61 & .53 \\
\hline & male & 172 & 2.5000 & .67484 & & & \\
\hline \multirow[t]{2}{*}{ ATE } & female & 188 & 3.2367 & .85191 & 358 & .28 & .77 \\
\hline & male & 172 & 3.2645 & 1.01080 & & & \\
\hline
\end{tabular}

As Table 8 shows, there is a statistically significant difference $[\mathrm{df}=358, \mathrm{t}=2.71$, sig (two-tailed) $=.007<.05]$ between females $(\mathrm{N}=188, \mathrm{M}=3.94, \mathrm{SD}=.52)$ and males $(\mathrm{N}=172, \mathrm{M}=3.78, \mathrm{SD}=.53)$ regarding message reduction (MES) in favor of females.

Also, a significant difference $[\mathrm{df}=358, \mathrm{t}=2.90$, sig (two-tailed) $=.004<.05]$ was found between females $(\mathrm{N}=188$, $\mathrm{M}=4.10, \mathrm{SD}=.79)$ and males $(\mathrm{N}=172, \mathrm{M}=3.85, \mathrm{SD}=.89)$ regarding their use of nonverbal strategy (NVS) in favor of females. Results did not show any statistically significant difference between males and females regarding their use of other strategies.

\section{Discussion and Conclusion}

Results of the current study revealed that individuals with different MI profiles use different speaking strategies. This finding is analogues to the findings of Shangarffam and Zand (2012) who found significant relationships between students' three types of intelligences and their use of oral communication strategies.

According to the results of the current study a positive correlation was also found between musical intelligence and fluency-oriented and accuracy-oriented strategies. One interpretation for this finding may be the relationship between musical intelligence and linguistic intelligence. Fonseca-Mora, Toskano-Fuentes, \& Wermke (2011), found the correlation between high linguistic intelligence and high musical intelligence (as cited from Mohammadzadeh \& Jafarigohar, 2012). Since linguistic intelligence concerns with language ability and also both types of accuracy-oriented and fluency-oriented strategies deal with linguistic features, it seems that there is a relationship between using these types of strategies and linguistic intelligence. Subsequently with regards to the high relationship between linguistic and musical intelligence, the observed relationship between musical intelligence and accuracy-oriented and fluency-oriented strategies can be justified. Positive relationship between musical intelligence and fluency-oriented strategies may also be explained in terms of the definition of this type of intelligence. According to Gardner (1983), musical intelligence refers to sensitivity to rhythm, pitch or melody, so those students who are more musically intelligent pay more attention to the rhythm, intonation and pronunciation of their sentences and may be more concerned with using fluency-oriented strategies.

Findings of this study also indicate significant relationship between visual intelligence and social affective and negotiation for meaning while speaking strategies. Pishghadam, Khodadady and Khoshsabk (2010), in their study found that students who learn words visually are more able to remember words and make sentences. Since word retention and having the ability of making sentence are two factors which are very important in speaking it can be concluded that visually intelligent students are good in speaking and negotiation. On the other hand, significant positive correlation 
was found between both of these strategy types and speaking fluency in the study of Metcalfe \& Noom-Ura (n.d), so based on the results of these two studies, it can be claimed that students who are more visually intelligent are good speakers and are therefore more willing to use such strategies.

Regarding the gender differences in speaking strategy use, results of data analysis showed that female subjects were superior users of message reduction strategies and nonverbal strategies. In a similar line of inquiry Moriam (2005) conducted a study in order to compare speaking strategy use of Japanese and Bangladeshi EFL learners. It was found that female Japanese college learners use more oral communicative strategies in compare with their male counterparts. Sobhani, Motallebzadeh and Ashraf (2014) in another study found that male and female students are different in using communication strategies in their email communications.

The present study aimed to explore the relationship between Iranian intermediate EFL learners' musical and visual intelligences and their use of speaking strategies in communication. Results of data analysis revealed significant relationship between musical intelligence and fluency-oriented and accuracy-oriented strategies. Furthermore, significant relationship was found between visual intelligence and social affective strategies and negotiation for meaning strategies. This finding is similar to the finding of Metcalfe \& Noom-Ura (n.d), who found significant relationship between both of these strategy types and speaking fluency. Findings also revealed that there is a significant difference between male and female EFL learners in using message reduction and nonverbal strategies in favor of females.

Although Gardner's multiple intelligences theory attracted the attention of many researchers during past decades and many researchers emphasized the effectiveness of the application of MI theory, it seems that many instructors ignored the importance of individual variations. Teacher awareness of individual differences and applying various techniques and materials instead of considering all students the same may be very useful to improve learners' achievement. Teachers are required to use different activities and tasks which accommodate different types of intelligences and make the process of learning fair, easy and enjoyable. Considering each individual's special ability to learn may increase the sense of self confidence among them. EFL learners are recommended to increase their autonomy and independence by using speaking strategies. Curriculum designers are required to design learners' curriculum according to individual variation and use various activities and tasks for different students.

This study intended to investigate the relationship between musical and visual intelligences and EFL learners' use of speaking strategies. Further fruitful studies can be conducted to examine the possible relationship between other types of intelligences and use of speaking strategies. The current study was conducted among Iranian intermediate EFL learners while other studies can be done to examine the possible relationship between these variables among other participants with different levels of language proficiency. Furthermore, not only are there insufficient numbers of studies on the role of gender on using speaking strategies but also there is a relative lack of unity in the results of these studies so investigating gender differences in using speaking strategies may be another fruitful line for further research.

\section{References}

Brown, H. D. (2007). Principles of language learning and teaching (5th Ed.). New York: Pearson Education

Davar Asl Bandarabbasi, R., \& Karbalaei, A. (2013). The Study of the Relationship between Multiple Intelligences and Learning Strategies among Iranian EFL learners. European Online Journal of Natural and Social Sciences, 2(2), 143149.

Gardner, H. (1999). Intelligence reframed: Multiple Intelligences for the 21st century. Howard Gardner.

Gardner, H. (1993). Multiple intelligences: The theory in practice. Basic books.

Grainger, P. (2012). The impact of cultural background on the choice of language learning strategies in the JFL context. System, 40(4), 483-493. Retrieved from:http://www.sciencedirect.com/science/article/pii/S0346251X12000875

Hajhashemi, K., Akef, K., \& Anderson, N. (2012). The relationship between multiple intelligences and reading proficiency of Iranian EFL students. World Applied Sciences Journal, 19(10), 1475-1483.

Hajhashemi, K., \& Eng, W. B. (2010). A Validation Study of the Persian Version of McKenzie's Multiple Intelligences Inventory to Measure Profiles of Pre-University Students. Pertanika J. Soc. Sci. \& Hum, 18 (2), 343-355.

Heidari, F., \& Khorasaniha, N. (2013). Delving into the Relationship between LOC, MI, and Reading Proficiency. Journal of Language Teaching and Research, 4(1), 89-96.

Khosravi, M., \& Saidi, M. (2014). Investigating the Possible Relationship between Multiple Intelligences and Selfefficacy: The Case of Iranian EAP Instructors. Electronic Journal of Foreign Language Teaching, 11(1), 90-97.

Krejcie, R. V., \& Morgan, D. W. (1970). Determining sample size for research activities. Educ Psychol Meas.

López, M. M. (2011). Speaking Strategies Used by BA ELT Students in Public Universities in Mexico. MEXTESOL Journal, 35(1), 1-22.

McKenzie, W. (1999). Multiple intelligences survey.

Metcalfe, M., \& Noom-Ura, S. (n.d). Communication Strategy Use of High and Low Proficiency Learners of English at a Thai University. Retrieved from: 164.115.22.25/ojs222/index.php/LEARN/article/view/229 
Mistar, J., Umamah, A. (2014). Strategies Of Learning Speaking Skill by Indonesian Learners of English And Their Contribution To Speaking Proficiency. TEFLIN Journal, 25(2), 203-216.

Mitits, L., \& Sarafianou, A. (2012). Development of Language Learning Strategies In Multilingual Vs. Monolingual Learners: Empirical Evidence From A Combined Methods Longitudinal Case Study. Retrieved from: www.icgl.gr/files/.../38.Mitits_\&_Sarafianou_10ICGL_pp.453-462.pdf

Mohammadzadeh, A., \& Jafarigohar, M. (2012). The Relationship between Willingness to Communicate and Multiple Intelligences among Learners of English as a Foreign Language. English Language Teaching, 5(7), 25.

Moriam, Q. (2005). Speaking Strategy Use by the EFL Students in Japan and Bangladesh. Pertanika J. Soc. Sci. \& Hum, 12 (1), 47-61.Retrived from: http://ir.lib.hiroshimau.ac.jp/metadb/up/kiyo/AN10482914/JIDC_12-1_47.pdf

Motallebzadeh, K. (2009). The relationship between the emotional intelligence of Iranian EFL learners and their reading comprehension and structural ability. Journal of Teaching English as a foreign Language and Literature, 1(4), 39-55.

Nakatani, Y. (2006). Developing an oral communication strategy inventory. Modern Language Journal, 90, $151-168$.

O'malley, J. M., \& Chamot, A. U. (1990). Learning strategies in second language acquisition. Cambridge University Press.

Pishghadam, R., \& Khodadady, E. (2010). The impact of visual and verbal intelligences-based teaching on the vocabulary retention and written production of Iranian intermediate EFL learners. The modern journal of applied linguistics, 2(5), 379-395.

Selinker (1972). interlanguage. IRAL, 10, 209-230.

Shangarffam, N., \& Zand, A. (2012). Iranian Foreign Language Learners' Multiple Intelligences and Their Use of Oral Communication Strategies. The Iranian EFL Journal, 8(4), 310-328.

Sobhani, A., Motallebzadeh, K., \& Ashraf, H. (2014) Iranian EFL Learner's Communication Strategies: Emails to Instructors. International Journal of Applied Linguistics \& English Literature, 3(2):64-74

Tam, K. C. H. (2013). A Study on Language Learning Strategies (LLSs) of University Students in Hong Kong. Taiwan Journal of Linguistics, 11(2), 1-42. 